\title{
THE IMPLICATIONS OF FACEBOOK IN POLITICAL MARKETING CAMPAIGNS IN CROATIA
}

\author{
Martinović, M., Pirić, V., Krkač, K.
}

Maja Martinović / Zagreb School of Economics and Management, Department of Marketing and Tourism, Jordanovac 110, Croatia.Email:mmartino@zsem.hr.

Valentina Pirić / Zagreb School of Economics and Management, Department of Marketing and Tourism, Jordanovac 110, Croatia. Email: valentina.piric1@gmail.com.

Kristijan Krkač / Zagreb School of Economics and Management, Department of Marketing and Tourism, Jordanovac 110, Croatia. Email: kristian.krkac@gmail.com.

\begin{abstract}
In the young Croatian democracy, there is a necessary role of the strategic approach to the political marketing communication campaigns, especially in using the new media, social networks and Facebook, being the most representative one. This paper aims to analyse to what degree the political parties use Facebook, how they manage this, and the opinions and viewpoints of the voters. This study has two major goals: to analyse how the leading political parties in Croatia use and manage social media services, particularly Facebook, and to evaluate perspectives of the Croatian voters regarding social media during political campaigns. Two instruments were created based on the secondary research: a protocol for in-depth semi-structured interviews conducted with the social media specialists of the leading Croatian political parties $(n=3)$ and a survey of voters $(n=557)$, ranging in age from $18-45$ years $(78.1 \%), 46-55$ years $(14.7 \%), 56-65$ years $(6.1 \%)$ and older than 66 (1.1\%). Croatian political parties do not use Facebook's entire potential. The respondents who vote regularly believe that the political parties' Facebook pages are significant in their promotion and visit these pages more frequently. These pages are visited more frequently during political campaigns. It is imperative to focus on increased quality and more frequent communication, direct communication and turning to young people in the campaigns. There are statistically significant differences with regard to age on the issue of voting. Croatian political parties can improve the potential of social networks, primarily Facebook, in election campaigns.

Implications for a Central European audience: In addition to the specified deficiencies of the Facebook pages, the voters provided suggestions for improving the Facebook content and increasing page visits. When used in combination with other social media, Facebook has the strongest potential for influencing the young voters. The results indicate the need for professional management of relevant social media strategies and tactics. The improvements of the Facebook pages can be grouped in several categories, the most important being "Content", "Communication" and "Strategy". The improvements would yield more frequent visits by the potential voters.
\end{abstract}

Keywords: political marketing; marketing campaigns; Facebook; Croatia JEL Classification: L38, L86, M31, P48 


\section{Introduction}

Over the last couple of decades, there has been an obvious market increase in research into marketing's relevance and its possible application to the fields of politics (Butler \& Collins, 1999; O'Shaughnessy, 2001; Peng \& Hackley, 2007; Pirić et al., 2016; Reid, 1988; Wring, 1997). Political participation is a multidimensional phenomenon (Norris \& Jones, 1998), and the major political parties in the developed world are embracing the marketing concept and process (Baines et al., 2002). Sparrow and Turner (2001) discuss how "political parties in Europe, following the trend in the USA, have entered a new era of the permanent election campaign".

Khatib (2012) has found basic factors that have a positive and significant effect on the success of political marketing, and they are market segmentation and targeting, candidate positioning and building strong image (to candidate and party). Depending on the level of citizen participation, Barber $(1984,2003 a)$ differentiates between "thin" democracy with relatively passive citizens, and "strong" democracy in which citizens actually participate in governing themselves. Fact is that a certain amount of time and effort must be invested in political participation, but less and fewer members of the community are ready to pay that price (Bošnjak et al., 2008). According to Krampen (1991), the extent to which an individual feels to be morally obliged to participate politically plays an important role in explaining the willingness to participate. Therefore it is extremely important to study people as consumers (Statt, 1997).

In general, this is the activity of non-profit marketing, in which people (i.e. personal branding) are of very high importance for the service offered. The basis for the research is the quality of information distribution from these same people via social networks, which represent a tangible part of the service through which voters perceive service as a whole. As an important moment, there are also processes related to the way and the course of communication answers to questions and general interaction with potential voters. However, not many authors have approached the subject of marketing in political campaigns as a study case of marketing service. One of the rare examples in literature comes from Nigeria. Worlu (2010) showed that there were significant differences in the contents of the marketing strategies employed by Nigerian parties, and it was recommended that parties should sharpen their strategies to be more issue-based and people-oriented. Another example investigates increasing use of social media as a platform for co-creative service innovation (CCSI) where customer innovativeness, attitude toward CCSI, subjective norm and perceived behavioural control positively influence both cocreation and adoption intention (Sarmah et al., 2018). The level and quality of services explored in this paper are related to the activities of political parties, following their events, as well as producing and publishing news. Thus, the publication of relevant information can be considered the service activity of a political party focused on voters.

In the young Croatian democracy, there is a necessary role of a strategic approach to political marketing campaigns, especially in using new media, social networks and Facebook, being the most representative one. This paper aims to analyse to what degree the political parties use Facebook, how they manage it, and the opinions and viewpoints of the voters. Therefore, this paper first focuses on how political parties perceive their own use 
of social networks, primarily Facebook, in the election campaigns. The perception, behaviour and motivation of the voters are then analysed, that is their general views on the relevance of Facebook in the promotion of political parties, followed by the motivation regarding visiting the Facebook pages of the political parties and frequency of visiting them. The voter's opinion on how many political parties exploit the communication potentials via Facebook is examined and what the biggest deficiencies of the Facebook pages in general are. Finally, the aim of the paper is to find out what improvements the voters propose to be made to those pages to make them more attractive and more frequently visited. The analysis of differences in views of two parties (the political party experts and the voters) leads to useful conclusions about the unmet needs of page users - the voters - and is the basis for further action in terms of improving the Facebook pages of the political parties.

The paper begins by reviewing the current literature regarding three fields: firstly, we start with a broader view and present the literature on the role of social media in political marketing campaigns, the next field refers to the implications of Facebook in marketing campaigns, and finally, we discuss online communication channels with voters in Croatia. The next section concentrates on the research approach that was applied in this study. In the following section, we present the main research results from in-depth semi-structured interviews and survey, followed by discussion. Finally, we present the conclusions as well as research implications and limitations.

\section{Literature review}

\subsection{Role of Social Media in Political Marketing Campaigns}

The internet could indeed overcome problems inherent to participation in offline associations, such as time and costs related to the use of physical meeting halls (Klein, 1999), and thus make participation more likely. But, loss of control, limited time, and resources are supposedly some of the reasons why parties are hesitantly using new digital communication tools (Klinger, 2013; Luders et al., 2014). Internet users are more socially active than non-users (Robinson et al., 2000), and there is a positive relationship between the intensity of Internet use and civic and political participation (Weber et al., 2003). Ways in which the internet can be used for political participation are numerous (Brack \& Noble, 2001; Nugent, 2001). Successful companies (political parties) allow users to create their own brand (party) experience (Callen, 2010).

Finally, in line with the reinforcement theory of online political participation (Barber, 2003b; Norris, 1999; Schuler, 2003), it could be concluded that online political participation is strongly predicted by past offline political participation. This means that the internet represents just another channel for political actions of those people who are already politically active in more traditional ways, rather than as an opportunity for activation of previously politically inactive people (Bošnjak et al., 2008). According to Edelman (2007), in past years, consumers are switching to the usage of social networks and are spending much more time with online marketing than with any other marketing channel. It has been observed that in the very short time, politicians in modern democracies across the world have adopted social media for engaging their constituents, entering into direct dialogues with citizens (Hong \& Nadler, 2012; Kruikemeier et al., 2016). Social media marketing is different than traditional marketing methods; therefore, it requires special attention and strategy building to achieve brand image and loyalty (Erdogmus \& Cicek, 2012). 
Several studies have documented how to direct dialogue with voters is mentioned as one of the main motivators for political parties and politicians to use social media (Enil \& Skogerbø, 2013; Karlsen, 2009, 2011; Udanor et al., 2016). The research also shows that politicians use different media, e.g. Facebook and Twitter, for different purposes (Stier et al., 2018). To communicate with voters/consumers properly, one must understand their motivation, the driving force within individuals that impels them to action. Therefore, marketers must view motivation as the force that includes consumption and, through consumption experiences, the process of consumer learning (Schiffman et al., 2008). Actually, consumers (voters) should be considered as problem-solvers, and their purchase or any kind of activity is a direct response to a problem (Solomon et al., 2010).

U.S. politicians are said to have a leading role in using social media, with the example of Barack Obama being able to successfully employ social media within his election campaign (Aharony, 2012; Wattal et al., 2010). A review of the evidence leaves no doubt that election campaigns do matter in a variety of important ways (Jacobson, 2015). Combination of complementary social media communication strategies have an effective impact on the reputation, and the number of interactions and the time taken to respond to customer's questions improve the reputation and provide communication that is more effective (Floreddu and Cabiddu, 2016). As suggested by Neti (2011), social media offers three advantages: listening customers' grievances and suggestions; identifying various peer groups and influencers among groups; and, all this can be done at nearly zero cost as the most social networking sites are free.

As suggested by Mangold and Faulds (2009), social media is a part of the promotional mix and, among other things, proposed the following to guide interactions to achieve positive impact: create communities of people who share interests, engage customers using social networking, appeal to a range of customers by combining marketing tools, etc. This indicates that in the political marketing context, social media can be used as a platform for co-creating value with consumers/voters (Kao et al., 2016). Therefore, the potential of using social media for political parties marketing is enormous.

\subsection{The Implications of Facebook in Marketing Campaigns}

In our work, we have primarily researched the current status and potential of Facebook as the most frequently visited social network in Croatia. The number of male and female users of the social networks in Croatia between age 13 and $65+$ is as follows: Facebook 2.000.000 users, Instagram 880.000 users, and Twitter 60-90.000 users (Starčić, 2017). Facebook is also present in over 70 countries and is constantly growing (Internet World Stats, 2017; Carlson, 2011; Techtree News Staff, 2008) with a global penetration rate of $26.3 \%$, and a growth rate of $282.3 \%$ from 2010 to 2017 .

According to Eurostat, the general trend for the individual social network users in 2019 is that $55 \%$ use at least one social network (Eurostat, 2019a). This trend continues and grows in 2020. The research regards dominantly social networks such as Facebook and Twitter. According to the European Commission (2020), the model expected rise of the global number of users is 0.2 billion per year. According to the Eurostat, in the average of $50 \%$ E.U. users, the split is $90 / 10 \%$ between Facebook and Twitter (and other social networks) users. The use by Croatian businesses is a bit lower then E.U. average which is $50 \%$, and 
for Croatia, it is $46 \%$ (Eurostat, 2019b). This should be important because it relates to political parties more correctly then the general population usage.

Croatia has around 2 million users of social networks and that they split into 1.900 .000 on Facebook, 100.000 on Twitter, and other social networks (Arbona, 2019). Complete data for 2020 are still not available, but some of them suggest that the average user spends at least $40 \%$ of waking hours on social networks (Smrekar, 2020). It is reasonably assumed that this number will rise due to various private and professional reasons related to COVID-19 pandemic and self-isolation measures. Some authors suggest that there is an "infodemic" going on parallel to the pandemic, such as Iwai in the paper "Harnessing Social Media for the COVID-19 Pandemic" (2020). Other sources based on statistics of use by the very social networks, such as Facebook, suggest the rise of $40 \%$ in use during the first three months of 2020 (Perez, 2020).

Because Facebook is becoming a new marketing tool for companies to enhance their brand awareness, they need to adopt new marketing policies and strategies that are different from others (Ramsaran-Fowdar \& Fowdar, 2013). The emergence of Facebook as a marketing platform has ushered a new era of personalised and directed advertising and social interaction (Maiz et al., 2016; Rasmaran-Fowdar \& Fowdar, 2013). According to Marder et al. (2018) "acquiring "Likes" for a political party or candidate's Facebook pages is important for political marketers. The authors Sakas et al. (2015) have even tried to analyse the brand awareness of Facebook and the competitive advantage that it creates. Facebook allows companies to connect with many more people and much more often than companies would be able to approach through phone calls, emails, or meetings (Luke, 2009). The study with U.S. consumers (Carlson et al., 2018) investigates how brand pages on Facebook have become instrumental in enabling customers to voluntarily participate in providing feedback/ideas for improvement and collaboration with others that contribute to the innovation effort of brands. Bronstein (2013) found that the Facebook pages are mostly used for fund-raising purposes, and for the mobilisation of supporters, while the numbers of comments and likes given to the posts were influenced by the element of persuasion used on the posts. Yang et al. (2008) reported that the advent of targeting ads, specifically toward demographics (age, sex, education, and so on), and tighter restrictions on ad quality, has turned Facebook advertising into a viable traffic builder and advertising option for small and large size businesses. One of its main benefits is in lower marketing costs. Advertising media and web metrics include impressions, gross rating points and opportunities-to-see, cost per thousand impressions (CPM) rates, reach/net reach and frequency, frequency response function, effective reach and effective frequency, the share of voice, impressions, page views and hits, click-through rates, cost per impression, cost per click and cost per acquisition, as well as visits, visitors and abandonment (Farris et al., 2006). And this is how political parties should track the effectiveness of their online activities, putting this time Facebook in particular focus, having in mind a cost-effective way of communication with different kind of audiences, as well as the large possible impact. In addition to a certain resistance in political marketing among those who should use it, when analysing the application of marketing in the Croatian political sphere, Šiber (2000) also cites some objective circumstances that make its application difficult, such as lack of funds. It is clear that the new circumstances of the growth of the internet and social networks can greatly contribute to its prosperity. 


\subsection{Online communication channels with voters in Croatia}

Although democracy in Croatia is relatively young, citizens already have plenty of opportunities for political discourse on the internet. The Croatian web sphere includes a number of web sites, blogs and forums dedicated to political discussion, the Croatian government and most major political parties have their own websites, and even the sessions of the Croatian Parliament is for a long period of time available via online streaming (Bošnjak et al., 2008). The recent study (Bagić Babac \& Podobnik, 2018) of posts and user comments published on Facebook during the 2015 parliamentary election campaign in Croatia shows that political parties implement different strategies on social media to influence citizens. Particularly, political messages with positive emotions evocate positive response, while neutral content is more likely to invoke negativism or criticism and support to the opponent. Also, two-way and tolerant communication of political actors increases citizen engagement, whereas unidirectional communication decreases it.

In this paper, we are particularly exploring whether political parties use the entire potential of social media marketing and social networks, as well as concrete suggestions for improving social network communication. This study contributes to a less examined field of online political communication (Kalsnes, 2016).

\section{Research approach}

Since the objective of this research is to understand the effect of social media marketing and particularly the use of Facebook services on communicating with voters during election campaigns, in the first part of the primary research the data were collected from social media specialists of the leading Croatian political parties. The second part addresses the views and opinions of the Croatian electorate, which uses the internet as a channel for information search, election campaign monitoring, perception of the activities and the performance of the political parties.

Therefore, this paper has two research questions, the first one being: the analysis of Facebook shortcomings will indicate how to improve the Facebook pages of the Croatian political parties to yield more frequent visits by potential voters. The other research question relates to the analysis of the differences and discrepancies between one side (the political party experts) and the other one (the voters).

To investigate these research questions, the following analyses were carried out:

- Individual interviews with Facebook experts were conducted at three parties in the Republic of Croatia, to identify how they perceived their own use of social networks, primarily Facebook, in the election campaigns.

- A survey was conducted on a convenience sample of social network users and Facebook social campaign followers in the view of their perception of the parties on the social networks.

Finally, the objective of the research was to investigate whether the parties, in the framework of reduced campaign funding, are using the full potential of cheaper and more efficient means to compensate for this deficiency.

Specifically, the above mentioned primary researches can be analysed separately, but can also be compared to show a discrepancy, i.e. a disproportion between the parties' 
perception of their actions on social networks and the perceptions of the voters on these actions. If a discrepancy is identified, then it is clear that social networks are not used to their maximum extent in the campaigns. The instruments (in-depth semi-structured interviews and survey questionnaires) for both primary types of research were designed to take into account the already existing instruments, as well as the methods used in similar studies in other countries. Namely, the questionnaires and surveys were compiled and adapted to the Croatian reality based on related studies conducted in Denmark (Andersen \& Medaglia, 2009), Jordan (Yousif \& Alsamydai, 2012), Albania (Gambarov et al., 2013), Finland and France (Ramos, 2015) and Norway (Kalsnes, 2016).

\subsection{Research results and discussion - in-depth semi-structured interviews}

Based on the secondary research, that is, the previously mentioned studies that were conducted in individual countries (Denmark, Jordan, Albania, Finland, France, and Norway) a protocol for in-depth semi-structured interviews was created for the first part of the primary research. Interviews were conducted with the social media specialists of three leading Croatian political parties, which have actively shaped the politics over the last few years including two parliamentary electoral cycles and one presidential election, with a change in the government. The questionnaire was designed in the form of a reminder for the individual interview with a total of 19 open questions and distributed to the email addresses of the parties whose experts then turned in completed questionnaires.

Below is Table 1, containing a total of 13 select responses to the questions posed in the interviews. The responses to the other six questions are more extensive and relate to descriptions of individual practices or opinions of respondents, and are provided in the text that follows that describes the overall results obtained as part of this research.

Table 1 I Responses to the questions in the individual interviews

\begin{tabular}{|c|c|c|c|}
\hline Political parties & 1 & 2 & 3 \\
\hline $\begin{array}{l}\text { Do you have a Facebook account? } \\
\text { Does your party president have a Facebook account? } \\
\text { Are accounts administrated by dedicated persons? } \\
\text { Are these persons experienced enough to adequately } \\
\text { administer the websites? } \\
\text { Are these persons professionally trained for the job? } \\
\text { Are these persons paid? } \\
\text { Do you expect relevant influence on voters? } \\
\text { Are expectations fulfilled? } \\
\text { Do you know on how many voters you influenced? } \\
\text { How many times per day you publish posts? } \\
\text { How often do you respond to negative comment? } \\
\text { Did you exhaust all the possibilities of the social network use? } \\
\text { Is it necessary to improve the communication through social } \\
\text { networks? }\end{array}$ & $\begin{array}{l}\text { yes } \\
\text { yes } \\
\text { yes } \\
\text { yes } \\
\text { no } \\
\text { yes } \\
\text { yes } \\
\text { yes } \\
\text { no } \\
3-4 x \\
\text { never } \\
\text { no } \\
\text { yes }\end{array}$ & $\begin{array}{c}\text { yes } \\
\text { yes } \\
\text { yes } \\
\text { yes } \\
\text { no } \\
\text { yes } \\
\text { yes } \\
\text { yes/no } \\
\text { no } \\
3-4 x \\
\text { seldom } \\
\text { no } \\
\text { yes }\end{array}$ & $\begin{array}{c}\text { yes } \\
\text { yes } \\
\text { yes } \\
\text { yes } \\
\text { no } \\
\text { yes } \\
\text { yes } \\
\text { yes/no } \\
\text { no } \\
4 x \\
\text { seldom } \\
\text { no } \\
\text { yes }\end{array}$ \\
\hline
\end{tabular}

Source: authors

The responses showed that all three parties are present on Facebook and that presidents of each party also have their own Facebook page. All the parties were asked whether the pages are administered by a dedicated person, and the answers were again affirmative. 
The next question was related to the fact whether these persons were experienced enough to adequately administer the websites. All the parties responded affirmatively (one party stressed that the relevant person had a 'long-term experience'). The parties answered negatively to the question about professional training for social network administration of these persons. The questions of whether these experts are paid for their job, and whether the party had a prediction of the impact of the social networks on swing voters were answered by all parties affirmatively. The next question concerned the level of expectation of the parties; they responded mostly with "high" (one party replied: "We cannot give this information"). For the question about whether the expectations were fulfilled, two responses were "in part", and one was "to a greater extent". The next question - what the reason was that the expectations were met or not met - was answered by the parties with the advantages of communicating via social networks, especially Facebook, but the answers differed. Some pointed out Facebook's "penetration", others pointed "short and clear messages to target groups", "timing options", while some pointed the importance of an "established team", "additional promotion" and "creativeness in the approaches to promotion". On the question related to whether the parties were aware of the impact of using social networks on the percentage of votes they got in the elections, the majority response was "We do not know," while one party replied that it did not conduct such research; thus the answer is the same. Next question was related to what methods of communication with the potential voters were used on social networks, and all the respondents replied that they used all available methods of communication. On how frequently the parties were publishing news on their sites, most of the parties responded "34 times a day", with the exception of one party which responded "a maximum of 4 posts a day, in 3 hours intervals (the responses apply to Facebook, while for Twitter one party responded "constantly"). On question related to how often they responded to negative comments, the responses differed significantly, varying from "we respond to any negative comment" (offensive comments on any basis whatsoever are deleted and the users warned that they would be blocked if such behaviour would continue), over "seldom" to "never". question about how they responded to negative comments - was again replied very differently. The response "Not at all" is consistent with the response "Never" for the previous question. Some of the respondents replied "In a reasonable and argued manner" and some "By providing information or data", "Affirmatively", by "Referring the users to people on the field and a member of parliament". On question related to the average amount of time needed to respond to a message received in the inbox, the answers ranging from "2 minutes on average", over " in the beginning 1-2 days on average, and later 20 minutes", to "1-2 days and later even less promptly". On question concerned whether the parties thought they had exhausted the opportunities for promoting the party and their leaders on Facebook, all the parties responded with "No" (one party also responded that "the real challenges for party and leaders promotion are still ahead"). All parties responded affirmatively on the question about whether they felt necessary to improve the communication through social networks. The last question about the ways to improve communication through social networks for the forthcoming elections was again answered differently. Some argue that "better and more frequent communication in the comments" is important, some that "it is important to include more people (MPs, candidates, etc.)", and that "direct communication" and "turning to the young people in the campaign" were important. 


\subsection{Research results and discussion - survey}

The second primary research addresses the views and opinions on using Facebook in the political campaigns of the Croatian electorate which uses the internet as a channel for information search, election campaign monitoring, perception of the activities and the performance of the political parties. It was conducted via Google Forms on a convenience sample of 557 respondents. The questionnaire was anonymous and developed for adult persons who are members of the Croatian electorate.

Gender-wise, $56 \%$ of the respondents were women, and $44 \%$ were men, which corresponds roughly to the distribution of the population of Croatia age $15+$ by gender in the last census. (Of a total of 3.632 .461 people over the age of 15, 1.900 .851 are women $52 \%$, and 1.731.610 are men - 48\%; (Central Bureau of Statistics, Croatia, 2011 Census)). According to the same census (Central Bureau of Statistics, Croatia, 2011 Census), just over a quarter of the population (25.8\%) live in the City of Zagreb and in the Zagreb County, the sample covers $59.9 \%$ of people in the area, while $40.1 \%$ of the respondents live in other Croatian counties.

When respondents were asked how regularly they take part in elections (1 - "Never", 5 "Always"), out of a total of 557 respondents, $67.3 \%$ answered that they always take part, while only $4.5 \%$ of them totally ignores them. The age of the respondents is an important limitation of this research, as there are a large number of younger respondents in the sample (structure by age ( $\mathrm{N}=557$ ): $18-25=26,4 \%$; $26-35=26 \%$; $36-45=25,7 \%$; $46-55=$ $14,7 \% ; 56-65=6,1 \% ; 66+=1,1 \%)$. Naimely, the last census shows roughly the following percentages: age 18-25 = 9\%; $26-35=16.1 \% ; 36-45=15.7 \% ; 46-55=17.3 \% ; 56-65=$ $16.1 \% ; 66+=20.7 \%$ (Central Bureau of Statistics, Croatia, 2011 Census). However, such distribution by age was to be expected with regard to the type of research and the sampling method. Specifically, the research covered new technologies and the Internet, and younger people tend to be online much more frequently.

Table 2 I Description of sample

\begin{tabular}{l|r}
\hline \multicolumn{2}{c}{ Gender } \\
\hline Male Age & $44 \%$ \\
Female & $56 \%$ \\
\hline \multicolumn{2}{c}{} \\
\hline $18-25$ & $26.4 \%$ \\
$26-35$ & $26 \%$ \\
$36-45$ & $25.7 \%$ \\
$46-55$ & $14.7 \%$ \\
$56-65$ & $6.1 \%$ \\
$>66$ & $1.1 \%$ \\
\hline \multicolumn{2}{c}{ Domicile } \\
\hline City and County of Zagreb \\
Other Croatian counties \\
\hline \multicolumn{2}{c}{ Frequency of voter turnout (5 - always; 1 - never) } \\
\hline 5 & $69.9 \%$ \\
4 & $16.3 \%$ \\
3 & $8.4 \%$ \\
2 & $3.4 \%$ \\
1 & $4.5 \%$ \\
\hline Source: authors
\end{tabular}


On a Likert's scale, the respondents indicated their view on the relevance of Facebook in the promotion of political parties; 1 designated "Not important" and 5 "Very important". Of the 557 respondents, the majority finds that Facebook is an important promotional tool for the party, as evident in Figure 1.

Figure 1 I General views on the relevance of Facebook in the promotion of political parties

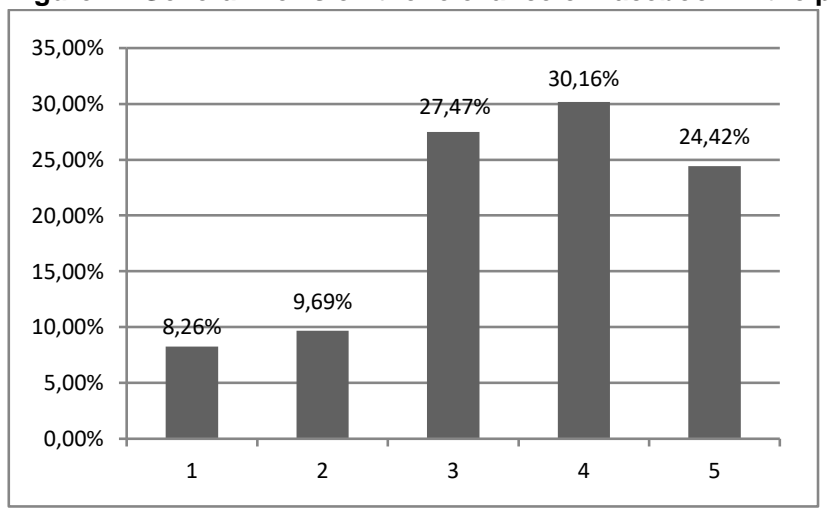

Source: authors

Of the total number of 557 respondents, 54.8\% have visited the Facebook page of a political party, while $45.2 \%$ did not. Those who did not (252 respondents) were asked for the reasons; $52 \%$ replied that they were not interested in any information about the parties, $28 \%$ said they prefer other sources of information on the parties and $20 \%$ replied that they are not Facebook users; hence they didn't visit the parties' pages. In response to the open question on what would it take for them to visit such pages on Facebook, the respondents replied in a manner that can be grouped into seven categories of responses. The objective here was to gain at least some suggestions from the respondents' replies on what one could do to induce them to become followers of the parties' Facebook pages. The first group of answers is "Nothing", also being the group with the largest number of respondents (121), followed by "Improvement of content" (36 responses). The other groups of open responses can be structured as follows:

Table 3 I Motivation of the respondents regarding the visiting of the Facebook pages of the political parties

\begin{tabular}{l|c}
\hline Responses & $\begin{array}{c}\text { Number of } \\
\text { respondents }\end{array}$ \\
\hline $\begin{array}{l}\text { Nothing } \\
\text { Interesting and informative content (featured party programs, plans and ideas, } \\
\text { page design, layout and photos, current news) }\end{array}$ & 36 \\
$\begin{array}{l}\text { Consistency, honesty and seriousness of the parties (acting in the general social } \\
\text { and national interest, who commit to promises made and speak the truth) }\end{array}$ & 20 \\
$\begin{array}{l}\text { Word of mouth and recommendation (if a family member is a party member if } \\
\text { friends advise following a certain party on Facebook) }\end{array}$ & 16 \\
$\begin{array}{l}\text { Documented communication and interaction with citizens and followers (credible } \\
\text { communication, constructive and argumentative discussion) }\end{array}$ & 10 \\
I don't know & 13 \\
$\begin{array}{l}\text { Other replies (I do not use Facebook, I have no interest in politics, negative } \\
\text { opinion on politics in general and lack of interest in following such content on }\end{array}$ & 36 \\
Facebook) & \\
TOTAL: & 252 \\
\hline
\end{tabular}

Source: authors 
Those respondents who visit the Facebook pages of the political parties $(N=305)$ were asked to specify how often they visited such pages (on a Likert scale: 1 - "Very rarely" to 5 "Very often, almost every day").

Figure 2 I Frequency of visiting the Facebook pages of the political parties

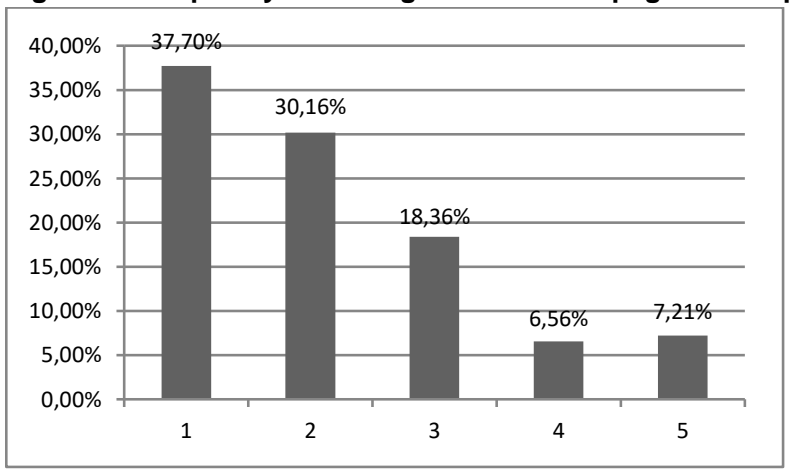

Source: authors

Out of the total number of respondents, $37.7 \%$ visit the pages very rarely, $30.2 \%$ rarely, and $7.2 \%$ on almost a daily basis (Figure 2). When asked whether they visited the Facebook pages of the political parties during political campaigns more frequently, $67.2 \%$ replied "Yes", 23\% replied negatively, and $9.8 \%$ did not know.

Of the total number of respondents who visit the Facebook pages of the political parties ( $\mathrm{N}$ $=305), 27.2 \%$ replied that they have communicated with the party via Facebook, while $72.8 \%$ have never done so. Out of the 83 respondents who have tried to communicate with the party, $68.7 \%$ got an answer, only $48.2 \%$ of them said that the reply was satisfactory, and $62.7 \%$ said that they received a reply in a reasonable time.

The respondents who are visiting the Facebook pages of the political parties $(\mathrm{N}=305)$ were asked about the intensity of the communication potentials of the political parties via their Facebook pages. Their replies on a Likert scale range from 1 - "Not at all" to 5 - "Yes, fully". The results show the highest response rate in the middle of the scale (37.7\%), towards a lower intensity of exploitation; thus the respondents generally find that the Facebook pages still have a lot of untapped potentials (Figure 3).

Figure 3 I Level up to which the political parties exploit the communication potentials via Facebook

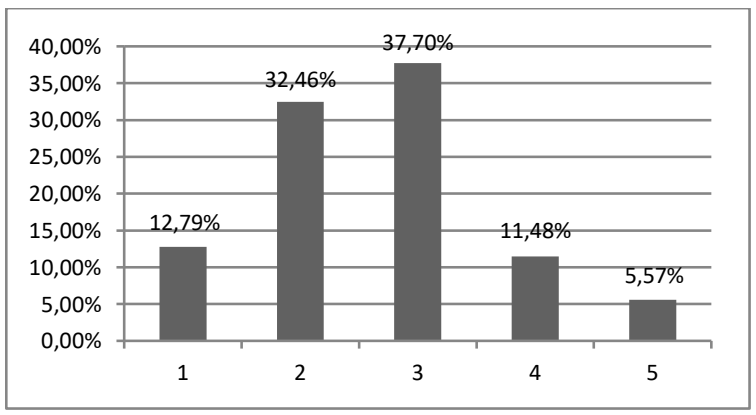

Source: authors 
When asked whether the Facebook page of a political party influenced their voting decision and if so to what extent, the respondents stated on a Likert scale 1 - "No influence whatsoever"; 5 - "Very high influence". Most of the respondents were not influenced when visiting the pages $(65.2 \%)$, while with very high influence we can identify only $1,6 \%$ respondents.

The respondents visiting Facebook $(\mathrm{N}=305)$ evaluate (on a Likert scale range from 1 "Not at all" to 5 - "Yes, fully") if these pages are up-to-date, of high quality and interesting. More than $80 \%$ of the respondents find the pages mediocre, unattractive and very poor in terms of up-to-dateness, quality and attractiveness. Given the scope of the content, an additional question was posed, and $67.8 \%$ of the respondents replied that they find the pages to have a mediocre scope and attractiveness, $22.1 \%$ do not know, and only $10.1 \%$ find the content to be extensive.

When asked if they would be more likely to visit the Facebook page of the political parties if the content was more attractive, respondents answered as follows: $25.9 \%$ would surely visit the pages, $47.5 \%$ probably would, $16.4 \%$ would not, and $10.2 \%$ do not know.

Only four respondents were unable to detect any disadvantages of the pages, while the other respondents indicated the general largest disadvantages of the Facebook pages of the political parties in the Republic of Croatia. Their responses can be tiered into 13 groups (Table 4) which ultimately can be categorised into the following six groups: Content of the Facebook posts (response groups 1, 2, 3, 7 and 8); Poor and inadequate communication (groups 5, 9 and 10); Poor strategy (group 6); Generally negative viewpoints and opinions about the parties that affect the perception of the Facebook pages (group 4); I don't know (group 11); and Other (group 12).

The "Content" group has a total of 137 responses (44.9\%), "Communication" has 57 responses (18.7\%), "Strategy" has 17 (5.7\%), "Opinions" 29 (9.5\%), "I don't know" 30 (9.8\%) and "Other" 31 (10.2\%).

The respondents believe that some improvements (Table 5) should be introduced on the pages, as they would visit the pages more frequently, which would then in itself be more interesting as well. Only three respondents were unable to detect any disadvantages of the pages, while the other improvements can be tiered into 11 groups which ultimately can be categorised into the following six groups: Content of the Facebook posts (response groups 2, 3, 4 and 5); Poor and inadequate communication (groups 1 and 7); Poor strategy (group 8); Generally negative viewpoints and opinions about the parties (group 6); I don't know (group 9); and Other (group 10). The "Content" group has a total of 110 responses (36\%), "Communication" has 66 responses (21.6\%), "Strategy" has 6 (2\%), "Attitudes" 14 (4.6\%), "I don't know" 51 (16.7\%) and "Other" 55 (18\%). 
Table 4 I Largest deficiencies of the Facebook pages in general

\begin{tabular}{|c|c|c|}
\hline Group & Largest deficiencies & $\begin{array}{l}\text { Number of } \\
\text { respondents }\end{array}$ \\
\hline 1. & $\begin{array}{l}\text { Outdated and inactive (active mostly during election times, irregular posts } \\
\text { of current topics) }\end{array}$ & 42 \\
\hline 2. & $\begin{array}{l}\text { Boring and uninteresting subjects (lack of interesting news from local } \\
\text { communities, unattractive approach to various topics) }\end{array}$ & 32 \\
\hline 3. & $\begin{array}{l}\text { Poor content/lack of quality content and programs (too extensive posts, } \\
\text { low-quality and incomprehensible content) }\end{array}$ & 31 \\
\hline 4. & $\begin{array}{l}\text { Insincerity, immorality, non-transparency, inconsistency, unfulfilled } \\
\text { promises }\end{array}$ & 29 \\
\hline 5. & $\begin{array}{l}\text { Poor communication (lack of bilateral communication, discussion and real } \\
\text { interaction, refusal of accepting criticism and deletion of negative } \\
\text { comments) }\end{array}$ & 25 \\
\hline 6. & $\begin{array}{l}\text { Poor media management strategy (poor and basic level P.R., lack of } \\
\text { elaborated campaigns, unsuitable media approach, lack of understanding } \\
\text { of the targeted audience: insufficient focus on the younger population, but } \\
\text { also neglecting the older population that is not using F.B. on a frequent } \\
\text { basis) }\end{array}$ & 17 \\
\hline 7. & Unimaginative, uncreative and uninventive posts & 16 \\
\hline 8. & $\begin{array}{l}\text { Non-informative (not a source of new information, posting/sharing already } \\
\text { known material, and with a delay) }\end{array}$ & 16 \\
\hline 9. & $\begin{array}{l}\text { Criticising other parties (using Facebook for the purpose of self- } \\
\text { promotion, lack of self-criticism, crosstalking of the parties and offensive } \\
\text { communication) }\end{array}$ & 16 \\
\hline 10. & $\begin{array}{l}\text { Incompetent F.B. page administrators (improper wording, unprofessional } \\
\text { attitude, misspelling and lack of etiquette) }\end{array}$ & 16 \\
\hline 11. & I don't know & 30 \\
\hline 12. & $\begin{array}{l}\text { Other (I can not answer the question, I do not visit the Facebook pages of } \\
\text { political parties, I have no opinion, I don't care about politics, I do not use } \\
\text { Facebook) }\end{array}$ & 31 \\
\hline 13. & There are no deficiencies & 4 \\
\hline \multicolumn{2}{|l|}{ TOTAL: } & 305 \\
\hline
\end{tabular}

Source: authors

Table 5 I Improvements to the Facebook pages to increase the frequency of visiting them

\begin{tabular}{c|l|c}
\hline Group & \multicolumn{1}{c|}{ Improvements } & $\begin{array}{c}\text { Number of } \\
\text { respondents }\end{array}$ \\
\hline 1. & $\begin{array}{l}\text { Improved communication with the visitors (interaction, polls, public } \\
\text { discussions, debates, replying to questions, live stream, live chat, } \\
\text { accessibility and response promptness, more personalised approach, } \\
\text { improved crisis P.R. and communication skills) } \\
\text { Upgrading quality of the content (more attractive design, shorter posts } \\
\text { and texts, topics which are more adapted to the citizens, more diverse } \\
\text { content - video footage and photos, informative announcements) } \\
\text { Up-to-dateness and activities (daily/weekly current news and topics, } \\
\text { more frequently - several times a day) } \\
\text { Interesting, creative, humorous and fun content }\end{array}$ & 59 \\
4. & 24 \\
\hline
\end{tabular}


5. Presentation of the activities and program of the party and its members, goals and achievements

6. Honesty, reality, objectivity, transparency selection of experts competent to manage Facebook pages and willing to interact with the followers)

8. Commitment and orientation to the younger population (daily interaction, specific content matched with the group's interests, encouraging young people to deal with political issues)

9. I don't know, I do not use Facebook, I don't care about politics

10. Other (comments such as: I have no interest, I would never visit their pages, they should know for themselves, I don't want to answer this question...)

11. No improvements needed

Source: own research

When asked if there is a party in the Republic of Croatia that is distinguished by the good quality of its Facebook content, most respondents think that there is none $(41.6 \%), 23.3 \%$ replied positively [the respondents mostly quoted HDZ (44\%), Živi zid (18\%), Pametno $(10 \%)$ and SDP $\left.(9 \%)^{1}\right]$, and $35.1 \%$ did not know.

When analysing the sub-sample based on the respondents' statement whether they have visited (or not) the pages of a political party, it is evident that in the sub-sample of the respondents who have not visited the Facebook pages the percentage of women is slightly higher (59.36\%); also, the average age in that sub-sample is higher. Among those respondents who visited the Facebook pages, there is a higher apprehension of the importance of the pages, and those respondents are more inclined to think that Facebook is becoming an important part of marketing in the promotion of the political parties. Interestingly, among those who did not visit the political parties' Facebook pages, a third of the respondents $(29.54 \%)$ estimated that Facebook was less important than the other marketing elements, while in the sub-sample of the Facebook page visitors about a tenth $(13.4 \%)$ of the respondents shared the same view.

By applying the ANOVA analysis, it is possible to conclude that there are statistically significant differences with regard to age on the issue of voting. The frequency of voting increases with age $(F=5.707, p<0.01)$. Of the 558 respondents, $376(67.4 \%)$ stated that they always take part in elections. Among those who vote on a regular basis, the prevailing sentiment is that the Facebook pages are an important promotional medium $(x=3.61)$ compared to those who do not regularly vote $(x=3.33)$. This difference has shown to be statistically significant $(F=7.030, p<0.01)$. At the same time, those who vote more often also visit more frequently the political parties' Facebook pages $(x=2.31)$ compared to others $(x=1.73, F=14.560, p<0.01)$.

1 HDZ - Hrvatska demokratska zajednica (engl. Croatian Democratic Union) is a liberal conservative political party and the main centre-right political party in Croatia. Živi zid (engl. Human Shield, literally translated as "Living Wall") is a populist political party in Croatia. Pametno (engl. Intelligently) is a liberal political party in Croatia. SDP Socijaldemokratska partija Hrvatske (engl. the Social Democratic Party of Croatia) is a social-democratic political party and the largest party of the Croatian centre-left. 


\section{Conclusion}

All the parties were able to recognise some of the benefits of communicating with the potential voters via Facebook, but not a single party was able to list all the advantages, such as low cost, highly targeted, global and/or local, available 24/7, and above all interactive. Not a single party is aware of the impact of high-quality use of social networks, suggesting that they have no clear predictions. Except for one party whose employee has many years of experience in social network management, the parties generally do not have staff educated for administering their Facebook pages. The differences in the answers to the question of how often they respond to negative comments show that the parties understand the communication via Facebook differently, so it is possible that some of the parties fail to understand that responding to comments and prompt feedback is as important as the content. The parties are aware that they do not use all the features and that they need to improve communication on social networks. The parties have identified the following improvements that are necessary: better and more frequent communication, the involvement of more people (representatives, candidates, etc.), direct communication and orientation to the younger population in the campaigns. This is also supported by the viewpoints and opinions of the electorate on using Facebook in the political campaigns. This is also part of the response to the research question concerning the analysis of differences and discrepancies between political parties and the other party (the voters). Specifically, the analysis shows that voters also have additional suggestions for improvements that are needed to increase their motivation to visit the political parties' Facebook pages, which are listed below. Depending on the groups of voters and whether they have already visited the pages or not, the parties can gain from their proposals valuable information on how to approach which segment.

Most voters who have participated in the research find that Facebook is an important promotional tool for the party, and most have visited such sites. The Facebook page of the political parties are more frequently visited during political campaigns; thus, a special strategy should be applied for such periods. Although most of the respondents who have communicated with a political party via Facebook got a reply to their questions, nevertheless, in some of the cases, no feedback whatsoever was received. This is an abominable behaviour towards potential voters and is directly related to the lack of use of interactivity. In addition, very often, even when a reply was received, it was unsatisfactory or not timely. Although the parties recognise that communication needs to be improved, such a view of the voters also gives them a detailed insight into what to do. The importance of enhanced interactivity is underlined by the study already mentioned with regard to U.S. consumers (Carlson et al., 2018) which investigates how brand pages on Facebook have become instrumental in enabling customers to voluntarily participate in providing feedback/ideas for improvement and collaboration with others that contribute to the innovation effort of brands.

For most of the respondents, visiting the parties' Facebook pages did not influence their voting decision. Most respondents find the pages to be poor in content and attractiveness, and they claim that they would visit the pages more often if the content was more attractive.

Most people who do not visit the Facebook pages of the political parties cannot be stimulated in any way to start visiting/following them, with a generally negative view of politics in general, which is entirely consistent with the claim that the internet represents just 
another channel for political actions of those people who are already politically active in more traditional ways, rather than as an opportunity for activation of previously politically inactive people (Bošnjak et al., 2008). There are still some suggestions for improvement. Namely, the respondents indicated the general largest disadvantages of the Facebook pages of the political parties in the Republic of Croatia. Their responses can be ultimately categorised into the six groups, the largest group being the shortcomings related to the content of the Facebook posts. As voters gave a more detailed insight into what they consider to be poor content, citing specific examples, this is certainly part of the answer to the research questions: The analysis of Facebook shortcomings will indicate how to improve Facebook pages of the Croatian political parties to yield more frequent visits by potential voters. The same is true of the other shortcomings of the Facebook pages, of which voters further emphasise poor and inadequate communication and poor strategy. Lacking strategy, poor access, or lack of understanding of particular voting groups may be related to the fact that parties consider the site administrators to be sufficiently experienced rather than invest in their training and education. Pramod et al., (2017) suggest that political messages are perceived differently by age-based voting cohorts in terms of message evaluation, believability and attitudinal dispositions. Older voter cohorts are more receptive to complex and detailed messages, while younger cohorts are more receptive to short and brief communication.

Additionally, improvements can be made in these areas of Facebook pages, and the aforementioned can lead to an increase in frequency and number of visits. The proposed improvements can be grouped into the categories, above all the following three: "Content", "Communication" and "Strategy". It is clear that by improving these segments, significant advances in the promotion via Facebook could be achieved. Again, those segments are closely related to the skills of the social network administrators.

In addition, we determined the reasons why some voters do not visit the parties' websites or Facebook pages. Most of those who have not visited the pages are not interested in information about the parties, while others have provided valuable information about what might encourage them to do so. Based on the grouping of their open responses, we marked seven categories which describe the motivation of the respondents regarding visiting the Facebook pages of the political parties. The voters would be primarily motivated by an improvement of content, followed by consistency, honesty and seriousness of the parties, word of mouth and credible communication, constructive discussion and interaction with citizens and followers.

Respondents who regularly vote also believe that the political parties' Facebook pages are important for their promotion and visit these pages more frequently. It is evident that in the sub-sample of the respondents who have not visited the Facebook pages, the percentage of women is slightly higher (59.36\%); also, the average age in that sub-sample is higher.

We can conclude that the analysis of the responses of both parties revealed certain similarities in part related to the necessary improvements to the Facebook pages of political campaigns. For both respondents (the parties and the voters), it is imperative to focus on increased quality and more frequent communication, direct communication and turning to young people in the campaigns. Research shows that the use of Facebook in political discussions, in particular, has a significant positive impact on the interest that young people show toward political issues (Pap et al., 2018; Stilin, 2020). Therefore, improvements in this 
particular segment appear to be vital. Voters have explained the shortcomings in this research in more detail, which can be a good way to address the existing gap. In addition, voters pointed out additional shortcomings and gave an opinion on what would motivate them to visit the pages more often. Thus, we can say that both research questions were answered.

\section{Research implications and limitations}

Since practical implications of this paper came as a result of the comparison of attitudes and thinking from different angles of view, i.e. different stakeholders, the obtained results provide a useful insight to differences in perception of the parties and their target audience. However, our study shows that Croatian political parties do not use the Facebook potential and obvious lack of quality, frequency and substance of Facebook communication services. Besides that, there are significant differences in Facebook perception due to age, and the different impact of Facebook on various voter segments. All these and other results and findings regarding Facebook can be applied to all other social networks during election campaigns.

Additionally, the numerous recommendations of the respondents regarding the content of the Facebook pages of the political parties could also be used for improving all social networks. For both respondents (the parties and the voters) it is imperative to focus on increasing quality in the content of messages, communicating more frequently and directly, targeting younger population in the campaigns to fully exploit the potential of Facebook and other social networks during election campaigns.

Political managers need to be aware of different groups within the electorate. Since segmentation in political campaigns, as a rule, is based on differences in attitudes, this research can be a very good platform for segmentation and determination of strategies and tactics of future political campaigns in the Republic of Croatia and beyond. In a political marketing campaign, the attitude can be a very useful segmentation variable. Specifically, the attitudes that people have in relation to a bid can be divided into five groups: enthusiastic, positive, indifferent, negative or hostile. For example, an "activist" in political campaign uses knowledge of an existing voter's attitude and, on the basis of it, estimates in advance how much time he/she will spend with the voter. He/she acknowledges enthusiastic voters and reminds them to vote; providing little or no losing time to those who are negative or hostile; he seeks to strengthen the attitude of those who are positive and tries to get the vote in those who are indifferent (Kotler \& Armstrong, 1993, p. 197). Further, targeted ads are more effective, and they lead to substantial saving in the advertising budget. Therefore, some authors already proposed a methodology for determining the political orientation of users on social network (Facebook) sites which might be adopted for targeting political messages, especially during election campaigns (David et al., 2016).

Political marketers can achieve greater credibility and effectiveness by following guidelines: construct "shallower" political marketing messages when targeting younger voting cohorts through the social network or Facebook, or "deeper" messages for older voters (Pramod et al., 2017). This provides valuable conclusions for the political public and activists inside and outside the borders of the Republic of Croatia. It also provides a valuable foundation for generating more successful political marketing plans, strategies and tactics. In addition, our research method is applicable in different countries if adaptations to macro-environment are 
undertaken (PESTLE model) (Kotler et al., 2014, pp. 74-84). As a next practical implication of our study, we would like to stress that publishing through social networks gives greater opportunities to smaller parties in comparison with parties that exist for many years and have more resources. Namely, using social networks enables communication with lower costs and allows campaigns under more equal conditions.

As there are three goals of each political campaign, namely: "raising voters' turnout in elections, publicising the qualities of a political subject and raising money, as well as recruiting campaign activities" (Stilin et al., 2010), content on social networks such as Facebook can significantly contribute to the achievement of any of these goals, which further contributes to the importance of the analysis done in this research.

Although the results are very applicable in practice, there are some weaknesses and limitations of this research, such as the age of the respondents, as a sample contains a larger number of young respondents. However, given the sampling method, this was difficult to control. Specifically, this is a convenience sample of respondents, which covers a slightly larger proportion in the City of Zagreb and Zagreb County in relation to the existing population distribution in the Republic of Croatia, which can also be considered as a limitation of the research. Concerning the type and scope of the research, this sampling method can be, however, accepted as justified. Further research limitation represents conducting primary research on Facebook services only. Also, the first part of our primary research is concerned only with three parties in one political system. However, this reflects the vast majority of electoral markets, and thus, further research could compare results across political systems. The research on Danish political parties (Ormrod \& Henneberg, 2011) has similar limitations in spite of which it contributes to understanding the concept of market orientation in the political sphere.

However, while potentials of Facebook usage for political communications were not exploited sufficiently in post-socialist and post-transitional societies, the authors believe that this framework could also be a base to other countries within Eastern Europe, and worldwide.

\section{References}

Aharony, N. (2012). Twitter use by three political leaders: an exploratory analysis. Online Information Review, 36(4), 587-603. https://doi.org/10.1108/14684521211254086.

Andersen, K. N. \& Medaglia, R. (2009). The Use of Facebook in National Election Campaigns: Politics as Usual? Research Gate. In A. Macintosh \& E. Tambouris (Eds.): ePart 2009, LNCS 5694 (pp. 101-111). Retrieved January 22, 2019, from https://www.researchgate.net/publication/221353459.

Arbona. (July 24, 2019). Facebook i Instagram u Hrvatskoj: zanimljive statistike - 2019. Retrieved April 10, 2020. Retrieved from https://www.arbona.hr/blog/drustveni-marketing/facebook-iinstagram-u-hrvatskoj-zanimljive-statistike-2019/2832.

Baines, P. R., Harris, P. H. \& Lewis, B. R. (2002). The Political Marketing Planning Process: Improving Image and Message in Strategic Target Areas. Marketing Intelligence \& Planning, 20(1), 6-14.

Bagić Babac, M. \& Podobnik, V. (2018). What social media activities reveal about election results? The use of Facebook during the 2015 general election campaign in Croatia. Information Technology \& People, 31(2), 327-347. https://doi.org/10.1108/ITP-08-2016-0200. 
Barber, B. R. (1984). Strong democracy: participatory politics for a new age, Berkeley: University of California Press.

Barber, B. R. (2003a). Which Technology and Which Democracy? In H. Jenkins \& D. Thorburn (Eds.), democracy and new media, Cambridge: The MIT Press (pp. 33-48).

Barber, B. R. (2003b). Democracy and Cyberspace: Response to Ira Magaziner. Which Technology and Which Democracy? In H. Jenkins \& D. Thorburn (Eds.), democracy and new media, Cambridge: The MIT Press (pp. 126-142).

Bošnjak, M., Galešić, M. \& Kliček B. (2008). Determinants of online political participation in Croatia. Društvena istraživanja, Zagreb, 17(4-5) (95-97), 747-769.

Brack, A. \& Noble, P. (2001). E-democracy around the world. Charleston, SC: Phil Noble \& Associates (for the Bertelsmann Foundation).

Bronstein, J. (2013). Like Me! Analysing the 2012 Presidential Candidates' Facebook Pages. Online Information Review, 37(2), 173-192. https://doi.org/10.1108/OIR-01-2013-0002.

Butler, P. \& Collins, N. (1999). A conceptual framework for political marketing. In B. I. Newman (Ed.), Handbook of Political Marketing, Sage, Thousand Oaks, CA (pp. 55-72).

Callen, B. (2010). Manager's Guide to Marketing, Advertising, and Publicity, McGraw-Hill, Madison, Wisconsin, 211.

Carlson, J., Rahman, M., Voola, R. \& De Vries, N. (2018). Customer engagement behaviours in social media: capturing innovation opportunities, Journal of Services Marketing, (32)1, 83-94. https://doi.org/10.1108/JSM-02-2017-0059.

Carlson, N. (2011). Goldman to clients: Facebook has 600 million users. Retrieved March 12, 2017, from http://www.msnbc.msn.com/id/40929239/ns/technology_and_science-tech_and_gadgets/.

Central Bureau of Statistics, Croatia (2011). Census, Retrieved November 12, 2019, Retrieved from https://www.dzs.hr/hrv/censuses/census2011/censuslogo.htm.

David, E., Zhitomirsky-Geffet, M., Koppel, M. \& Uzan, H. (2016). Utilising Facebook Pages of The Political Parties to Automatically Predict The Political Orientation of Facebook Users. Online Information Review, 40(5), 610-623.

Edelman, D. C. (2007). From the periphery to the core: as online strategy becomes overall strategy, marketing organisations and agencies will never be the same. Journal of Advertising Research, 47(2), 130-134.

Enil, G. S. \& Skokerbø, E. (2013). Personalised Campaigns in Party-Centred Politics. Information, Communication \& Society, 16, 757-774.

Erdogmus, I. E. \& Cicek, M. (2012). The impact of social media marketing and brand loyalty. 8th International Strategic Marketing Conference. Procedia Economics and Finance, 24 (2015), 1353-1360.

European Commission. (2020). Number of Social media users worldwide 2010-2017 with forecasts to 2021. Retreived April 8, 2020, from https://ec.europa.eu/knowledge4policy/visualisation/number-social-media-users-worldwide2010-17-forecasts-2021_en.

Eurostat. (June 29, 2019a). Are you using social networks? Retrieved April 8, 2020, from https://ec.europa.eu/eurostat/web/products-eurostat-news/-/EDN-20190629-1.

Eurostat. (2019b). Living online: what the internet is used for. Retreived April 8, 2020, from https://ec.europa.eu/eurostat/cache/infographs/ict/bloc-1b.html. 
Farris, P. W., Bendle, N. T., Pfeiffer, Ph. P. \& Reibstein, D. J. (2006). Key Marketing Metrics: The 50+ metrics every manager needs to know. Wharton School Publishing, FT Prentice Hall, 263.

Floreddu, P. B. \& Cabiddu, F. (2016). Social media communication strategies. Journal of Services Marketing, 30(5), 490-503.

Gambarov, V., Zenelaj, B. \& Belba, G. (2015). Marketing of Political Parties on Social Media, Research Gate, November 2015, 225-242. Retrieved December 16, 2018, from https://www.researchgate.net/publication/320076592.

Hong, S. \& Nadler, D. (2012). Which Candidates Do the Public Discuss Online in an Election Campaign? The Use of Social Media by 2012 Presidential Candidates and its Impact on Candidate Salience. Government Information Quarterly, 29(4), 455-461. https://doi.org/10.1016/j.giq.2012.06.004.

Internet World Stats. (June 30, 2017). Facebook Users in the World. Retrieved February 16, 2019, from https://www.internetworldstats.com/FB.htm.

lyer, P., Yazdanparast, A. \& Strutton, D. (2017). Examining the effectiveness of WOM/eWOM communications across age-based cohorts: implications for political marketers, Journal of Consumer Marketing, 34(7), 646-663.

Iwai, Y. (April 7, 2020). Harnessing Social Media for the COVID-19 Pandemic. Scientific American. Retrived April 10, 2020, from https://blogs.scientificamerican.com/observations/harnessingsocial-media-for-the-covid-19-pandemic/.

Jacobson, G. C. (2015). How do campaigns matter? Annual Review of Political Science, 18, 31-47.

Kalsnes, B. (2016). The Social Media Paradox Explained: Comparing Political Parties' Facebook Strategy Versus Practice. Social media + Society, 2(2), 1-11.

Kao, T., Yang M., Wu, J. B. \& Cheng, Y. (2016). Co-creating value with consumers through social media. Journal of Services Marketing, 30(2), 141-151.

Karlsen, R. (2009). Campaign communication on the internet: Party strategy in the 2005 Norwegian election campaign. Journal of Elections, Public Opinion and Parties, 19, 183-202.

Karlsen, R. (2011). Velgernes valgkamp. In B. Aardal (Ed.) Det politiske landskapet: En studie av strotingsvalgt 2009 - The political landscape. A study of the national election 2009, Cappelen Damm Akademisk, Oslo, Norway (pp. 41-64).

Khatib, F. S. (2012). Factors affecting success of political marketing: a Jordanian electorate point of view. Journal of Economic and Administrative Sciences, 28(1), 4-27.

Klein, H. (1999). Tocqueville in cyberspace: Using the Internet for citizen associations. The Information Society, 15, 213-220.

Klinger, U. (2013). Mastering the art of social media. Information, Communication and Society, 16, 717736.

Kotler, P. \& Armstrong, L. (1993). Marketing - An Introduction, 3rd edition, Prentice-Hall, Inc., New Jersey.

Kotler, P., Keller, K. L. \& Martinović, M. (2014). Upravljanje marketingom - 14 ed. (Marketing Management - 14 ed.), MATE, Zagreb.

Krampen, G. (1991). Political participation in an action-theory model of personality: Theory and empirical evidence. Political Psychology, 12, 1-25. http://dx.doi.org/10.2307/3791343. 
Kruikemeier, S., van Noort, G., Vliegenthart, R. \& de Vreese, C. H. (2016). The relationship between online campaigning and political involvement. Online Information Review, 40(5), 673-694. https://doi.org/10.1108/OIR-11-2015-0346.

Luders, M., Følstad, A. \& Waldal, E. (2014). Expectations and Experiences with McLabourParty: From right to know to right to participate? Journal of Computer-Mediated Communication, 19, 446462.

Luke, K. (2009). Marketing the new-fashioned way: connect with your target market through social networking sites. Journal of Financial Planning, November/December, 18-19.

Maiz, A., Arranz, N. \& de Arroyabe, J. C. F. (2016). Factors affecting social interaction on social network sites: the Facebook case. Journal of Enterprise Information Management, 29(5), 630649. http://dx.doi.org/10.1108/JEIM-10-2014-0105.

Mangold, W. G. \& Faulds, D. J. (2009). Social media: the new hybrid element of the promotion mix. Business Horizons, 52(4), 357-365.

Marder, B., Marchant, C., Archer-Brown, C., Yau, A. \& Colliander, J. (2018). Conspicuous political brand interactions on social network sites. European Journal of Marketing, 52(3/4), 702-724.

Neti, S. (2011). Social Media and it's Role in Marketing. International Journal of Enterprise Computing and Business Systems, 1(2), July, ISSN (Online): 2230-8849.

Norris, P. (1999). Who surfs Café Europa? Virtual democracy in the U.S. and Western Europe, paper for presentation at the Annual Meeting of the American Political Science Association, Atlanta: [17/11/2003].

Norris, P. \& Jones, D. (1998). Virtual democracy (Editorial). The Harvard International Journal of Press/Politics, 3, 1-4.

Nugent, J. D. (2001). If democracy is the answer, what is the question? National Civic Review, 90, 221233.

Ormrod, R. P. \& Henneberg, S. C. (2011). Political market orientation and strategic party postures in Danish political parties. European Journal of Marketing, 45(6), 852-881. https://doi.org/10.1108/03090561111119949.

O'Shaughnessy, N. (2001). The marketing of political marketing. European Journal of Marketing, 35(9/10), 1047-1057.

Pap, A., Ham, M. \& Bilandžić, K. (2018). Does social media usage influence youth's interest in politics? International journal of multidisciplinarity in business and science, 4(5), 2018.

Peng, N. \& Hackley, Ch. (2007). Political marketing communication planning in the U.K. and Taiwan: Comparative insights from leading practitioners. Marketing Intelligence \& Planning, 25(5), 483498.

Perez, S. (March 26, 2020). Report: WhatsApp has seen a $40 \%$ increase in usage due to COVID-19 pandemic. Retrieved April 8, 2020, from https://techcrunch.com/2020/03/26/report-whatsapphas-seen-a-40-increase-in-usage-due-to-covid-19-pandemic/.

Pirić, V., Krkač, K. \& Martinović, M. (2016). Political marketing communications and possible contribution of Facebook, social networks and the usage of new technologies in the Republic of Croatia. Journal of Advancements in Economics, Finance \& Accounting, VI(1), 53-65.

Ramos, E. (2015). Social Media as a Marketing Tool \& its Impact on Politics, thesis, Haaga-Helia, University of Applied Sciences. 
Ramsaran-Fowdar, R. R. \& Fowdar, S. (2013). The Implications of Facebook Marketing for Organisations. Contemporary Management Research, 9(1), March, 73-84. https://doi.org/10.7903/cmr.9710.

Reid, D. M. (1988). Marketing the Political Product. European Journal of Marketing, 22(9), 34-47.

Robinson, J., Kestnbaum, M., Neustadtl, A. \& Alvarez, A. (2000). Mass media use and social life among Internet users. Social Science Computer Review, 18, 490-501.

Sakas, D. P., Dimitrios, N. K. \& Kavoura, A. (2015). The development of Facebook's competitive advantage for brand awareness. International Conference on Applied Economics, ICOAE 2015, 2-4 July 2015, Kazan, Russia, Procedia Economics and Finance, 24, 589-597.

Sarmah, B., Kamboj, S. \& Kandampully, J. (2018). Social media and co-creative service innovation: an empirical study. Online Information Review, 42(7), 1146-1179. https://doi.org/10.1108/OIR-032017-0079.

Schiffman, L. G., Hansen H. \& Kanuk, L. L. (2008). Consumer Behaviour. A European Outlook. Pearson Education, 207-247.

Schuler, D. (2003). Reports of the close relationship between democracy and the internet may have been exaggerated. In H. Jenkins \& D. Thorburn (Eds.), democracy and new media. Cambridge: The MIT Press (pp. 69-84).

Smrekar, M. (February 6, 2020). Statistika ne laže: Živimo u digitalnom svijetu, 40 posto budnog vremena provodimo - na internetu, Retrieved April 10, 2020, from https://www.tportal.hr/tehno/clanak/statistika-ne-laze-zivimo-u-digitalnom-svijetu-40-postobudnog-vremena-provodimo-na-internetu-20200206, Tportal, 06.02.2020.

Solomon, M. R., Bamossy, G., Askegaard, S. \& Hogg, M. K. (2010). Consumer Behaviour: A European Perspective. Fourth Edition, FT Prentice Hall, Harlow.

Sparrow, N. \& Turner, J. (2001). The permanent campaign - The integration of market research techniques in developing strategies in a more uncertain political climate. European Journal of Marketing, 35(9/10), 984-1002.

Starčić, B. (2017). Analizirali smo društvene mreže u 2017 - pogledajte kako se stvari rade u svijetu, a kako kod nas. Retrieved December 20, 2018, from https://www.tportal.hr/tehno/clanak/analizirali-smo-drustvene-mreze-u-2017-pogledajte-kakose-stvari-rade-u-svijetu-a-kako-kod-nas-20171205, Tportal, 26.12.2017.

Statt, D. A. (1997). Understanding the Consumer: A Psychological Approach. MacMillan Business, London, 3-4.

Stier, S., Bleier, A., Lietz, H. \& Strohmaier, M. (2018). Election Campaigning on Social Media: Politicians, Audiences, and the Mediation of Political Communication on Facebook and Twitter. Political Communication, 35(1), 50-74.

Stilin, Ž. (2020). Impact of political marketing in digital environment on voters with regard to their age. Interdisciplinary management research (in publishing).

Stilin, Ž., Žunić, J. \& Németh, P. (2019). Using the E-marketing Tools in a Political Campaign. International Journal of Multidiciplinarity in Business and Science, 5(8), 5-12.

Šiber, I. (2000). Politički marketing i politički sustav, Politička misao: časopis za politologiju, XXXVII(2), 149-167.

Techtree News Staff. (2008). Facebook: largest, fastest growing social network. February 9, 2011. Retrieved December 20, 2018, from http://www.techtree.com/India/News/FB_Largest_Fastest_Growing. 
Udanor, C., Aneke, S. \& Ogbuokiri, B. O. (2016). Determining social media impact on the politics of developing countries using social network analytics. Program, 50(4), 481-507.

Wattal, S., Schuff, D., Mandviwalla, M. \& Williams, C. B. (2010). Web 2.0 and Politics: The 2008 U.S. Presidential Election and an E-Politics Research Agenda. MIS Quarterly, 34(4), 669-688.

Weber, L., Loumakis, A. \& Bergman, J. (2003). Who participates and why? An analysis of citizens on the internet and the mass public. Social Science Computer Review, 21, 26-42.

Worlu, R. E. (2010). Marketing Strategies of Nigerian Political Parties: A Comparative Analysis, Global Journal of Management and Business Research, 10(5), 48-63.

Wring, D. (1997). Reconciling marketing with political science: theories of political marketing. Journal of Marketing Management, 13, 651-664.

Yang, T., Kim, D. \& Dhalwani, V. (2008). Social networking as a new trend in e-marketing. In L. Xu, M. Tjoa \& S. Chaudhry (Eds.), Research and Practical Issues of Enterprise Information System II. Boston: Springer, 847-856.

Yousif, R. O. \& Alsamydai, M. J. (2012). The Impact of the Political Promotion via Facebook on Individuals' Political Orientations. International Journal of Business and Management, $7(10)$, 85-98.

The research paper passed the review process. | Received: February 27, 2020; Revised: April 17, 2020; Accepted: April 23, 2020; Published: September 30, 2020. 